\title{
Nutritional deficiency symptoms of young 'cedro doce' plants grown under macronutrient omission
}

\author{
Simone T. M. de Aquino ${ }^{1}$, Reila F. dos $\operatorname{Santos}^{1} \&$ Karine D. Batista $^{2}$ \\ ${ }^{1}$ Universidade Estadual de Roraima/Programa de Pós-Graduação em Agroecologia. Boa Vista, RR, Brasil. E-mail: simonetmoura@hotmail.com - ORCID: \\ 0000-0003-0756-6544; reilaferreirasantos@outlook.com - ORCID: 0000-0002-0661-5482 \\ ${ }^{2}$ Empresa Brasileira de Pesquisa Agropecuária/Centro de Pesquisa Agroflorestal de Roraima. Boa Vista, RR, Brasil. E-mail: karine.batista@embrapa.br \\ (Corresponding author) - ORCID: 0000-0002-8938-4877
}

\begin{abstract}
Cedro doce' [Pochota fendleri (Seem) Alverson \& Duarte] is a native forest species in Amazon with great ecological and economic importance. Understanding nutritional requirements of the species allows cultivating Pochota fendleri with more efficient fertilization practices since its initial growth, as a seedling. Thus, this research aimed to evaluate the symptoms of nutritional deficiency of young 'cedro doce' plants. The experiment was carried out from September to December 2016, under greenhouse conditions, at Embrapa Roraima, in Boa Vista, RR, Brazil. The experiment was a randomized complete block design with seven treatments [complete solution and individual omission of the macronutrients $(\mathrm{N},-\mathrm{P},-\mathrm{K},-\mathrm{Ca},-\mathrm{Mg},-\mathrm{S})$ ] and three replications. Each experimental plot corresponded to a pot with one plant, corresponding to 21 plots. At 77 days after transplanting the seedlings to the pots, the plants were evaluated for symptoms of nutritional deficiency: total height, collar diameter, leaf number, chlorophyll a and b, chlorophyll $a / b$ index ratio, shoot and root dry mass, and root/shoot ratio. The macronutrients omission caused nutritional deficiency symptoms in all 'cedro doce' plants. In general, $\mathrm{P}$ and $\mathrm{N}$ omission caused the least development of plants. This result is an indicative that 'cedro doce' is a high demanding species for both nutrients, especially phosphorus.
\end{abstract}

Key words: Pochota fendleri, native species, missing nutrient

\section{Sintomas de deficiência nutricional de plantas jovens de cedro doce cultivado sob omissão de macronutrientes}

RESUMO: O cedro doce [Pochota fendleri (Seem) Alverson \& Duarte] é uma espécie florestal nativa da Amazônia e com expressiva importância ecológica e econômica. Conhecer as exigências nutricionais da espécie permite cultivar o cedro doce com práticas de adubação mais eficientes desde a sua fase de muda. Sendo assim, o objetivo desta pesquisa foi avaliar os sintomas de deficiência nutricional de plantas jovens de cedro doce. O experimento foi conduzido de setembro a dezembro de 2016, em casa de vegetação da Embrapa Roraima, em Boa Vista, RR. O delineamento experimental foi em blocos casualizados, com sete tratamentos [solução nutritiva completa e com omissão individual dos macronutrientes (-N, -P, -K, -Ca, -Mg, $-\mathrm{S})$ ] e três repetições. Cada parcela experimental correspondeu a um vaso com uma planta, totalizando 21 parcelas. Aos 77 dias após o transplantio das mudas para os vasos, as plantas foram avaliadas quanto aos sintomas de deficiência nutricional: altura total, diâmetro do colo, número de folhas, índice de clorofila a e b, razão do índice de clorofila $a / b$, massa seca da parte aérea, massa seca da raiz e razão raiz/parte aérea. A omissão dos macronutrientes ocasionou sintomas de deficiência nutricional em todas as plantas de cedro doce. De maneira geral, a omissão de $\mathrm{P}$ e de $\mathrm{N}$ provocou o menor desenvolvimento das plantas. Esse resultado é indicativo de que o cedro doce seja uma espécie muito exigente em ambos os nutrientes, especialmente em fosforo.

Palavras-chave: Pochota fendleri, espécie nativa, nutriente faltante 


\section{INTRODUCTION}

From the Malvaceae family, 'cedro doce' [Pochota fendleri (Seem) Alverson \& Duarte] is an endemic timber species in several countries of Central and South America. In Brazil, the species occurs naturally only in forest ecosystems in the state of Roraima (Halfeld-Vieira et al., 2007). The wood of 'cedro doce' is mainly used for furniture manufacture due to its characteristics of resistance to the attack of termites, absence of odor and its mechanical properties very favorable to the furniture industry (Arco-Verde \& Moreira, 2002).

In the last decades, natural populations of 'cedro doce' have been under severe pressure due to wood and deforestation exploitation in the occurrence areas. Thus, there is the need for degraded ecosystems recovery and establishment of commercial planting of the species. Pochota fendleri cultivation will contribute not only to biodiversity maintenance (Andrade \& Boaretto, 2012), but also to raw material supply for timber market.

Native forest species or any other plant species need the correct nutrient supply at all physiological stages for satisfactory development (Malavolta et al., 1997). However, there is little information on the nutritional requirement for 'cedro doce'. It is necessary to develop research to define the nutritional requirements of the species, since this information is essential to provide subsidies that guarantee planting management (Souza et al., 2010).

Therefore, this study aimed to characterize macronutrient deficiency symptoms in young 'cedro doce' plants using the nutrient omission technique.

\section{Material ANd Methods}

The research occurred between September and December 2016, in a greenhouse at the Embrapa Roraima headquarters, whose geographic coordinates are $2^{\circ} 42^{\prime} 30^{\prime \prime} \mathrm{N}$ and $47^{\circ} 38^{\prime}$ 00 " W. During the experiment, mean values of temperature and relative humidity inside the greenhouse were $29^{\circ} \mathrm{C}$ and $71.6 \%$, respectively.

Pochota fendleri seeds were used from trees cultivated in the experimental field of Embrapa Roraima. Seeds were treated with $2 \mathrm{~mL}$ of fungicide Derosal ${ }^{\circledR}$ with $1 \mathrm{~L}$ water. They were in contact with the solution for $10 \mathrm{~min}$. After drying in the open air, seeds were sown in polyethylene bags filled with sand. The bottom of the container had a layer of gravel to avoid water accumulation. The sowing was irrigated whenever necessary.

The sand used in the experiment as substrate was washed with $10 \%$ hydrochloric acid solution $(\mathrm{v} / \mathrm{v})$ for $10 \mathrm{~min}$ and then rinsed with running water. Finally, it was rinsed four times with deionized water until the sand $\mathrm{pH}$ reached around value of 5.5 .

After 10 sowing days, $10 \mathrm{~cm}$ tall seedlings were transplanted to polyethylene pots with $2.5 \mathrm{~L}$ washed sand and irrigated with complete $(\mathrm{C})$ Hoagland nutrient solution (Table 1), with partial and individual omission of nitrogen $(-\mathrm{N})$, phosphorus $(-\mathrm{P})$, potassium $(-\mathrm{K})$, calcium $(-\mathrm{Ca})$, magnesium $(-\mathrm{Mg})$ and sulfur $(-S)$. As the plants were in the initial development stage, it was provided with $10 \%$ of the element concentration that would be omitted, in agreement to each treatment. If the plants received the nutrient solution with total omission of the missing element, at this stage, they would not develop and would not express the characteristic deficiency symptoms of each nutrient. From the $49^{\text {th }}$ day after transplanting, the $10 \%$ of the missing elements of the respective solutions used to irrigate the pots were removed. Substrate was not washed for the complete removal of the missing element because as the plants had already grown the nutrient demand would be greater than the availability of the omitted element in each pot.

From day 1 to day 14, after transplantation, the solutions contained $20 \%$ of the total ionic strength. From day 15 to day 22 , plants were irrigated with solutions at $50 \%$ ionic strength.

From day 23 until the end of the experiment, solutions with $100 \%$ ionic strength were used. Daily, from day 1 to day 14 , plants were irrigated with $1 \mathrm{~L}$ solution. From then until the end of the experiment, the volume of solution used for daily irrigation was $1.5 \mathrm{~L}$.

Under each pot, there was a pot to collect the drained solution after irrigation. Each pot was wrapped outside with aluminum foil to prevent light incidence in the nutrient solutions drained from each pot. Solutions had no contact with aluminum foil. The $\mathrm{pH}$ of the solutions was maintained between 5.8 and 6.2 by adjusting daily with solution of $\mathrm{HCl}$ or $\mathrm{NaOH}$. After adjusting the $\mathrm{pH}$, the volume of the solutions was completed to $1 \mathrm{~L}$ (or $1.5 \mathrm{~L}$, as explained above) using deionized water. The same solution was reapplied on the sand of the respective container to irrigate the plants. After complete drainage, the collecting pots were capped to prevent the incidence of light and algae growth in the solutions. Solutions were changed weekly.

The experimental design was in randomized blocks with seven treatments: complete nutrient solution (C) and

Table 1. Composition of nutrient solutions (100\% ionic strength) complete (C) and with $10 \%$ concentration of the missing elements: nitrogen $(-\mathrm{N})$, phosphorus $(-\mathrm{P})$, potassium $(-\mathrm{K})$, calcium $(-\mathrm{Ca})$, magnesium $(-\mathrm{Mg})$ or sulfur $(-\mathrm{S})$, in the respective solutions

\begin{tabular}{|c|c|c|c|c|c|c|c|c|}
\hline \multicolumn{2}{|c|}{ Stock solutions } & \multicolumn{7}{|c|}{$\begin{array}{l}\text { Volume of stock solution } \\
\text { to } 1 \mathrm{~L} \text { nutrient solution (mL) }\end{array}$} \\
\hline Reagents & $\left(\mathrm{mol} \mathrm{L}^{-1}\right)$ & C & $-\mathrm{N}$ & $-\mathbf{P}$ & $-K$ & $-\mathrm{Ca}$ & $-\mathrm{Mg}$ & $-S$ \\
\hline $\mathrm{KNO}_{3}$ & 1 & 4.80 & & 4.80 & & 4.80 & 4.80 & 4.80 \\
\hline $\mathrm{Ca}\left(\mathrm{NO}_{3}\right)_{2} \cdot 4 \mathrm{H}_{2} \mathrm{O}$ & 1 & 3.20 & $\underline{0.60}$ & 3.20 & 3.20 & $\underline{0.32}$ & 3.20 & 3.20 \\
\hline $\mathrm{NH}_{4} \mathrm{H}_{2} \mathrm{PO}_{4}$ & 1 & 0.80 & & & 0.80 & $\overline{0.80}$ & 0.80 & 0.80 \\
\hline $\mathrm{MgSO}_{4} .7 \mathrm{H}_{2} \mathrm{O}$ & 1 & 1.60 & 1.60 & 1.60 & 1.60 & 1.60 & $\underline{0.16}$ & $\underline{0.16}$ \\
\hline $\mathrm{NH}_{4} \mathrm{NO}_{3}$ & 1 & & & & 0.80 & 0.80 & & \\
\hline $\mathrm{NaNO}_{3}$ & 1 & & & & 3.20 & 4.80 & & \\
\hline $\mathrm{KH}_{2} \mathrm{PO}_{4}$ & 1 & & 0.80 & $\underline{0.08}$ & & & & \\
\hline $\mathrm{K}_{2} \mathrm{SO}_{4}$ & 0.5 & & 4.00 & & & & & \\
\hline$\left(\mathrm{NH}_{4}\right)_{2} \mathrm{SO}_{4}$ & & & & 0.40 & & & & \\
\hline $\mathrm{MgCl}_{2} \cdot 6 \mathrm{H}_{2} \mathrm{O}$ & 1 & & & & & & & 1.60 \\
\hline $\mathrm{Na}_{2} \mathrm{SO}_{4}$ & 1 & & & & & & 1.60 & \\
\hline $\mathrm{CaCl}_{2}-2 \mathrm{H}_{2} \mathrm{O}$ & 1 & & 2.00 & & & & & \\
\hline $\mathrm{KCl}$ & 1 & & & & $\underline{0.48}$ & & & \\
\hline Fe-EDTA* & & 0.80 & 0.80 & 0.80 & $\overline{0.80}$ & 0.80 & 0.80 & 0.80 \\
\hline Micronutrients ${ }^{\star *}$ & & 0.80 & 0.80 & 0.80 & 0.80 & 0.80 & 0.80 & 0.80 \\
\hline
\end{tabular}


with individual omission of the macronutrients $(-\mathrm{N},-\mathrm{P},-\mathrm{K}$, $-\mathrm{Ca},-\mathrm{Mg},-\mathrm{S})$ and three replicates. Each experimental plot corresponded to one pot with one plant, amounting to 21 plots.

At 77 days after transplanting, plants were evaluated for visual symptoms of nutritional deficiency, total height $(\mathrm{cm})$, distance between the substrate level and the apical bud; stem diameter ( $\mathrm{mm}$ ), using a caliper; number of leaves and chlorophyll (IChl) a and b index, through which the chlorophyll $\mathrm{a} / \mathrm{b}$ index ratio was obtained, using Clorofilog (Model CFL 1030, Falker). The IChls were measured in the central leaflet of the third and fourth leaves of each plant, between 8:00 and 10:00 A.M., local time. For statistical analysis, the mean of the two leaves was considered. Then plants were harvested and their shoot was separated from the root. The plant material was oven dried at $65^{\circ} \mathrm{C}$ for $72 \mathrm{~h}$ and then weighed to obtain the dry weight of shoot, root, and the root/shoot ratio.

Data were submitted to analysis of variance at 0.05 probability and means were compared with the Scott Knott test at 0.05 probability. The statistical program Sisvar was used (Ferreira, 2008).

\section{Results AND Discussion}

Plants grown in the complete nutrient solution (C) showed good development, with no nutritional deficiency symptom (Figures $1 \mathrm{~A}$ and $2 \mathrm{~A}$ ). The $-\mathrm{N}$ treatment reduced plant growth and showed leaves with chlorosis throughout the leaf blade (Figures 1A and 2C). Generalized chlorosis was observed, reaching new and old leaves throughout the plant.

$\mathrm{N}$ deficiency symptoms are common in old leaves, since this nutrient moves within the plant. When there are low $\mathrm{N}$ concentrations in the plant, the element is redistributed from

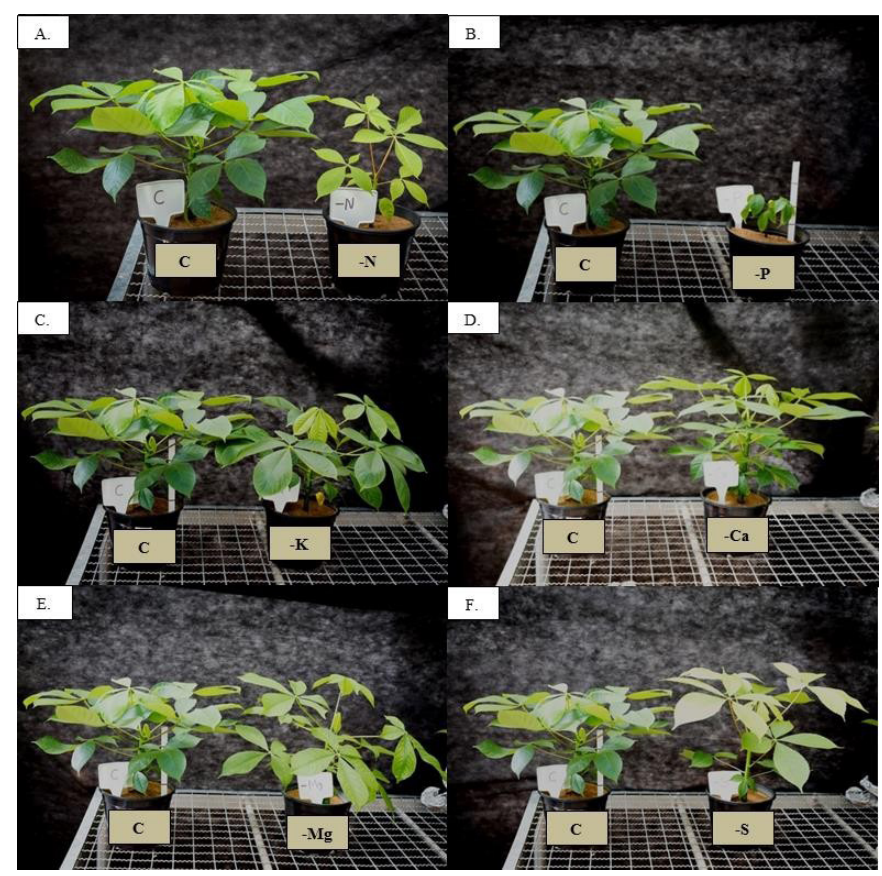

Figure 1. 'Cedro doce' plants grown in complete nutrient solution, $\mathrm{C}$ and with absence of nitrogen, $-\mathrm{N}(\mathrm{A})$; Phosphorus, -P (B); Potassium, -K, (C); Calcium, -Ca, (D); Magnesium, $-\mathrm{Mg}(\mathrm{E})$ and Sulfur $-\mathrm{S}(\mathrm{F})$

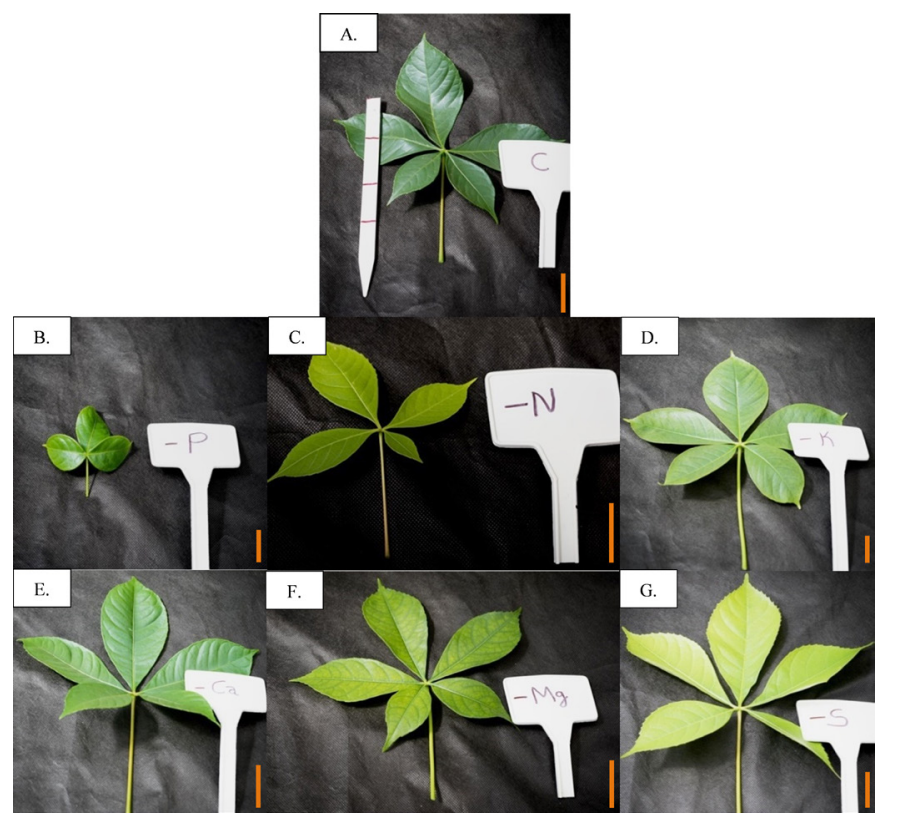

Each unit in the scale of the orange bar represents $6 \mathrm{~cm}$ in length

Figure 2. Visual symptoms of nutritional deficiency in 'cedro doce' leaves grown in complete nutrient solution, $\mathrm{C}(\mathrm{A})$; with absence of Phosphorus, -P (B); Nitrogen, -N (C); Potassium, -K (D); Calcium, -Ca (E); Magnesium, $-\mathrm{Mg}(\mathrm{F})$ and Sulfur, $-S(G)$

the old leaves to the new ones (Malavolta et al., 1997). However, when the deficiency evolves to a more advanced stage, the symptom may manifest throughout the plant (Andrade \& Boaretto, 2012), as observed in 'cedro doce' plants.

Chlorosis is a typical symptom of $\mathrm{N}$ deficiency because the nutrient is part of the chlorophyll molecule. Therefore, if there is reduction of $\mathrm{N}$ in the plant, chlorophyll degradation also occurs (Maillard et al., 2015). As the chlorophyll concentration in the leaf reduces, photosynthesis tends to decrease as well, resulting in a reduction of plant growth (Wallau et al., 2008).

The petiole of 'cedro doce' leaves under $\mathrm{N}$ deficiency showed a reddish coloration. This can be explained by the large accumulation of unused carbohydrates in the synthesis of nitrogen compounds. Excess of carbohydrates can be used in anthocyanin synthesis, which in turn gives red color to the tissue (Nemie-Feyissa et al., 2014). According to Diaz et al. (2006) the red coloration on Arabidopsis leaves is a symptom of anthocyanin accumulation and relates to aging and nutritional deficiency.

Figures $1 \mathrm{~B}$ and $2 \mathrm{~B}$ show a great reduction in the growth of the cultivated plants with $\mathrm{P}$ absence. Some leaflets had burning aspect in the apices.

Symptoms of $\mathrm{P}$ deficiency, similar to those observed in 'cedro doce', have been reported in African mahogany plants by Corcioli et al. (2014) and in cherry plant by Vieira et al. (2011) cultivated under P absence. P participates in the metabolism of several molecules, such as starch, fats and proteins. Additionally, $\mathrm{P}$ plays a structural role in the plant and is directly involved with the transfer and storage of energy. Therefore, when the nutrient is in suboptimal concentrations for the plants, growth reduction becomes evident (Marschner, 1995). 
Plants grown under $\mathrm{Mg}$ absence showed interveinal chlorosis in all leaves (Figure 2F). Similar symptoms, but in older leaves, occurred in Brazilian peppertree cultivated in nutrient solution with no $\mathrm{Mg}$ (Andrade \& Boaretto, 2012). As Mg is considered mobile in the plant (Marschner, 1995), nutrient deficiency symptoms were expected to appear first on older leaves. However, possibly Mg deficiency was very advanced at the time of symptom assessment and, therefore, interveinal chlorosis occurred in all leaves. Chlorosis is also expected because $\mathrm{Mg}$ is part of the chlorophyll molecule (Malavolta et al., 1997).

Visually, there was little or no difference between the plant sizes of treatments $\mathrm{C},-\mathrm{K}$ and $-\mathrm{Ca}$ (Figures $1 \mathrm{C}$ and $\mathrm{D}$; $2 \mathrm{D}$ and $\mathrm{E}$ ). Plants cultivated under $\mathrm{K}$ absence presented mild chlorosis throughout the leaf blade. Literature commonly presents record of chlorosis in older leaves of plants under K deficiency (Moretti et al., 2011; Sorreano et al., 2012). However, Camacho et al. (2014) observed that plants of Bombacopsis glabra (Pasquale) Robyns, cultivated under K deficiency, did not present visual $\mathrm{K}$ deficiency symptoms.

Ca deficiency in the culture medium reflects different consequences on the development of distinct plant species. Sorreano et al. (2011) and Andrade \& Boaretto (2012) presented a negative effect of $\mathrm{Ca}$ absence on the growth of young plants of Croton urucurana and Brazilian peppertree (Schinus terebinthifolius Raddi), respectively. However, Ca omission from the culture medium did not cause differences in the growth of seedlings of Pink trumpet tree Tabebuia impetiginosa, as reported by Souza et al. (2006), corroborating the results observed for Pochota fendleri. The results of this study suggest that young Pochota fendleri plants are not very demanding in $\mathrm{Ca}$ and $\mathrm{K}$ or have high efficiency of use of both nutrients.

Macronutrient omission, in general, resulted in reduced growth characteristics (plant height, stem diameter, number of leaves, shoot dry mass accumulation, SDM; root dry mass, RDM and total dry mass, TDM) in almost all treatments (Figures 1; 3A, B, C, D, E and F). Plants cultivated under $\mathrm{P}$ omission, followed by those cultivated under $\mathrm{N}$ absence presented the lowest values for all these variables.

Except for $\mathrm{P}$ and $\mathrm{N}$, omission of the other macronutrients did not interfere with plant height (Figures 1C, D, E and F; $3 \mathrm{~A}$ ). Only Ca omission was not enough to reduce the diameter of 'cedro doce' plants (Figure 3B).

Number of leaves reduced in plants grown in nutrient solution with absence of macronutrients, except for $-\mathrm{Mg}$ treatment (Figures $\mathrm{IE}$ and $3 \mathrm{C}$ ). As for dry mass accumulation, $\mathrm{Ca}$ omission was the one that least affected biomass accumulation in different parts of the 'cedro doce' plants (Figures 3D, E and F). Comparing to the control, plants cultivated under Mg omission showed lower SDM accumulation; however, the number of leaves was equal to the control. One explanation for this is the fact that the diameter of plants grown under $\mathrm{Mg}$ omission was smaller than the diameter of control plants (Figure 3B). Another possible reason is, although there was no leaf anatomy or
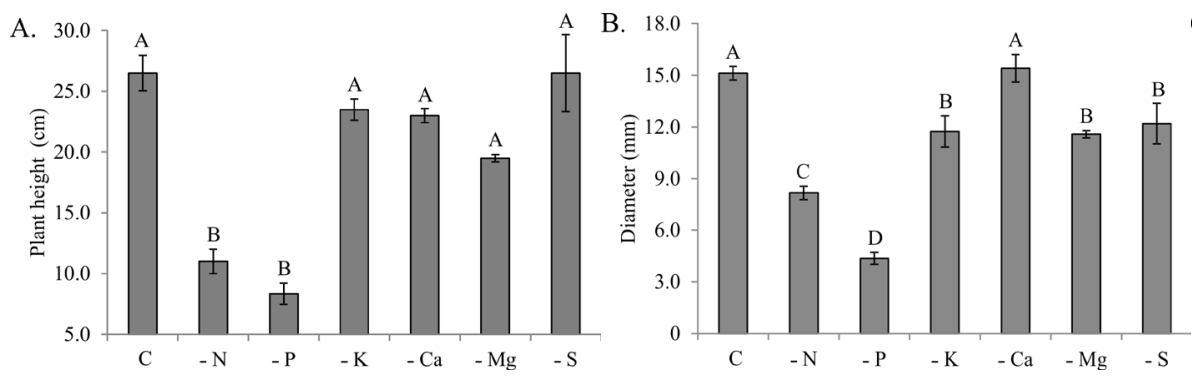

C. 20.0
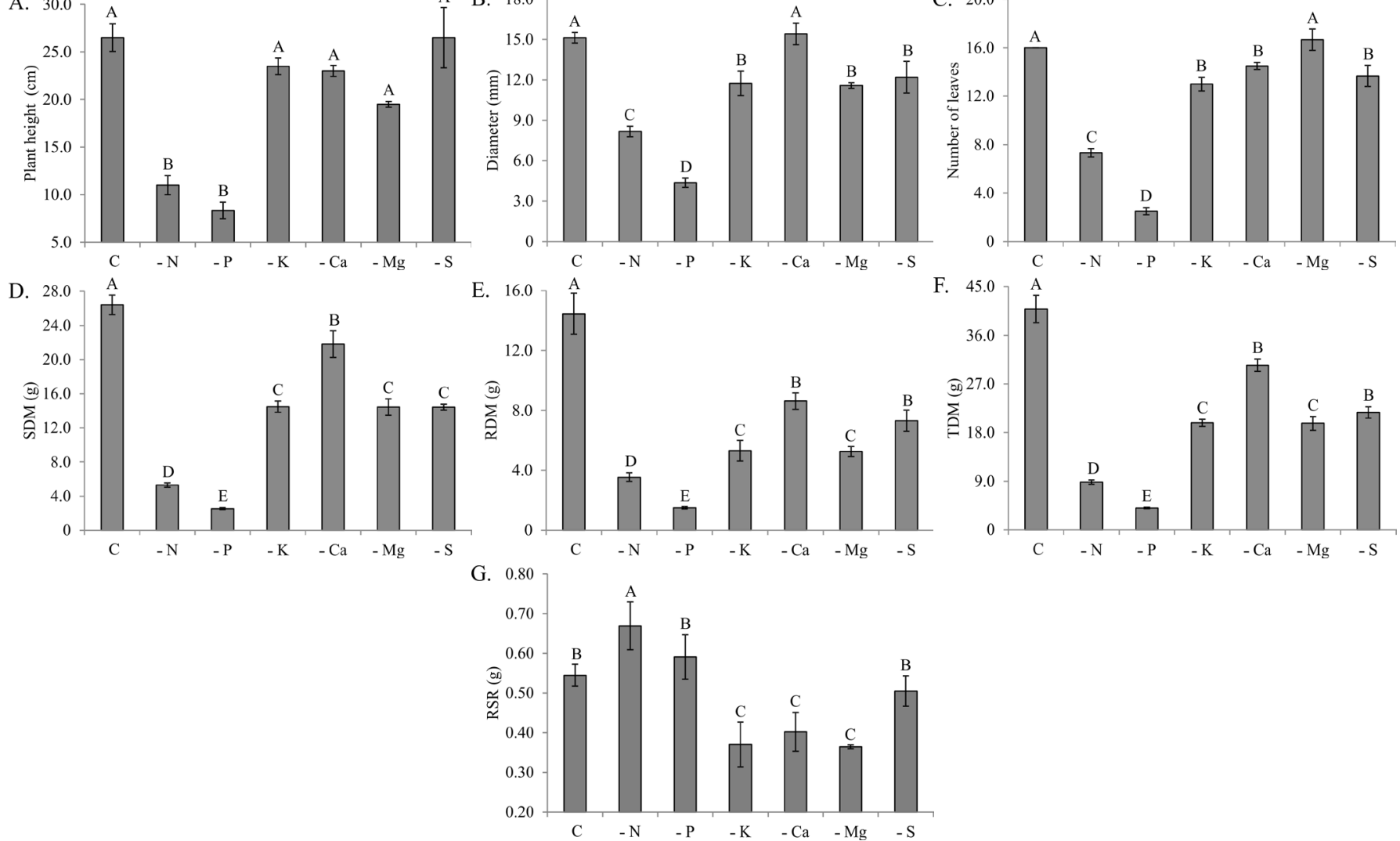

Same capital letters do not differ statistically from one another by the Scott Knott Test at 0.05 probability. Bar represents the standard error of the mean. $\mathrm{n}=3$

Figure 3. Plant height (A); stem diameter (B); number of leaves (C); shoot dry mass, SDM (D); root dry mass, RDM (E); total dry mass, TDM (F) and root/shoot ratio, RSR (G) of 'cedro doce' plants grown in complete nutrient solution (C), with absence of Nitrogen (-N), Phosphorus (-P), Potassium (-K), Calcium (-Ca), Magnesium (-Mg) and Sulfur (-S) 
morphology study in the present research, the thickness or the leaf expansion of the plants under $\mathrm{Mg}$ omission was probably smaller, which can contribute to the less dry mass accumulation in the shoot.

$\mathrm{P}$ omission resulted in the lowest values for plant height and stem diameter (Figures $3 \mathrm{~A}$ and $\mathrm{B}$ ). The same results were found for Tabebuia ochracea Cham. Standl. in which $\mathrm{P}$ omission was the most limiting in the plant height and diameter growth of seedlings (Vieira et al., 2016). According to Shen et al. (2011), this element plays a role in photosynthesis, respiration, cell division and growth, and energy transfer as part of adenosine triphosphate (ATP). Once there is $\mathrm{P}$ deficiency in plants, there is also a reduction in plant growth.

The reduction of shoot, root and total dry mass accumulation was evident in plants cultivated under macronutrient omission. However, it occurred with greater emphasis on plants with no $\mathrm{P}$ or no $\mathrm{N}$ culture mediums. The result indicates that young 'cedro doce' plants are very demanding in $\mathrm{N}$ and $\mathrm{P}$, according to Aquino et al. (2016).

Similar results were observed for Australian cedar cultivated under absence of macronutrients. The major limitations to SDM accumulation occurred when plants were cultivated under N, P, S and Ca omission (Moretti et al., 2011). In Brazil wood seedlings (Caesalpinia echinata Lam.), N omission limited SDM production (Valeri et al., 2014). However, TDM of Drumstick tree (Moringa oleifera Lam.) had no alteration when cultivated with no K, Ca and S (Vieira et al., 2008).

All the values observed for the root/shoot ratio (RSR) were lower than 1 (Figure $3 \mathrm{G}$ ), which means greater investment in shoot growth than in the root system. The 'Cedro doce' plants cultivated under $\mathrm{N}$ absence showed the highest RSR. In the absence of $\mathrm{K}, \mathrm{Ca}$ and $\mathrm{Mg}$, plants presented the lowest RSR. The RSR for the treatments $-\mathrm{P}$ and $-\mathrm{S}$ were similar to that presented by the control.

Results of root/shoot ratio (RSR) lower than one were also observed in studies with Cedrela odorata L., by Locatelli et al. (2007) and with eucalyptus (Swietenia macrophylla King), by Rocha et al. (2014). On the other hand, Moretti et al. (2011) reported that Australian cedar presented RSR greater than 1. It is evident that dry mass accumulation between the different parts of the plant varies among the species. According to Chen et al. (2009), RSR of Betula alnoides was higher in all treatments with nutrient omission, compared to control, except for treatment without Mg. RSR increase means greater investment for root growth in relation to the growth and development of shoot. Under low nutrient availability conditions, there is a tendency for greater root growth in search of greater absorption of the missing nutrient (Fonseca et al., 2010).

Different arboreal species submitted to cultivation under nutrient omission show different nutritional needs. Toona ciliata M. Roem var. australis (Australian cedar) showed limited initial growth when cultivated with no N, P, K, S and $\mathrm{Mg}$ and lower stem diameters in treatments without P, N, K and S (Moretti et al., 2011), corroborating with the observations in this study. In contrast, plants grown under Ca absence presented similar development in the control treatment, which is similar to that presented by 'cedro doce'.
The chlorophyll a index was lower in plants cultivated under $\mathrm{N}$ or $\mathrm{S}$ omission (Figure $4 \mathrm{~A}$ ). Chlorophyll $\mathrm{a} / \mathrm{b}$ ratio was lower only in the plants of the treatments $-\mathrm{P},-\mathrm{K}$ and $-\mathrm{Ca}$ (Figure 4C). Plants grown under $\mathrm{S}$ omission, similarly to those of the $\mathrm{N}$ treatment, reduced $\mathrm{IChl}$ a and $\mathrm{b}$ (Figures $4 \mathrm{~A}$ and $\mathrm{B}$ ), but maintained both indexes, because of the similarity between $\mathrm{Chl} \mathrm{a} / \mathrm{b}$ ratio of this treatment and the control.

It is known that $S$ is not a chlorophyll molecule constituent. However, this nutrient is part of ferredoxin, Fe-S protein present in chloroplasts and necessary for chlorophyll synthesis (Capaldi et al., 2015). Therefore, S deficiency compromises chlorophyll synthesis, which was visually evident with chlorosis in 'cedro doce' leaves under S deficiency (Figure 2G). In turn, $\mathrm{N}$ is part of the chlorophyll molecule (Muñoz-Huerta et al., 2013). Therefore, it is expected that plants grown in medium with low $\mathrm{N}$ or $\mathrm{S}$ availability show reduced IChl a and/or b values as observed for 'cedro doce' plants.

The $\mathrm{Chl} \mathrm{a/b}$ ratio reduction in $-\mathrm{K}$ and $-\mathrm{Ca}$ treatments occurred due to the increase of 61.2 and $31.0 \%$ in $\mathrm{Chl} \mathrm{b}$, respectively. According to Kitajima \& Hogan (2003), the low $\mathrm{N}$ availability in the culture medium causes an increase in the $\mathrm{Chl} \mathrm{a} / \mathrm{b}$ ratio. However, this result was not observed for 'cedro doce' plants as verified by the similarity of values between $\mathrm{Chl}$ $\mathrm{a} / \mathrm{b}$ ratio of the control and $-\mathrm{N}$ treatments.
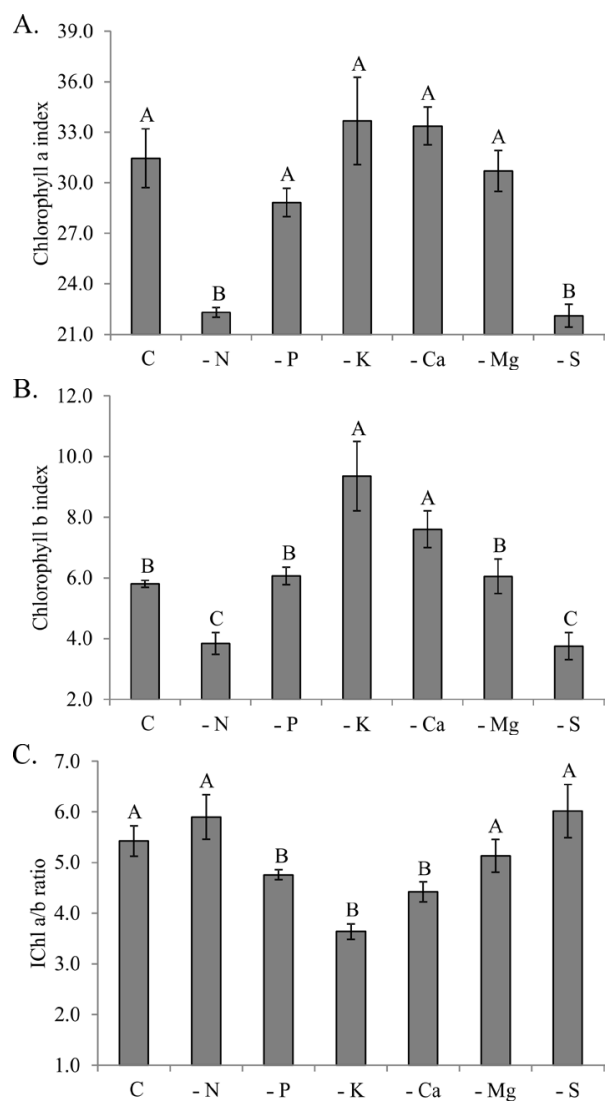

Same capital letters do not differ statistically from one another by the Scott Knott Test at 0.05 probability. Bar represents the standard error of the mean. $n=3$

Figure 4. Chlorophyll a (A) and chlorophyll b (B) index and chlorophyll a/b ratio index (IChl a/b ratio) (C) of 'cedro doce' plants grown in complete nutrient solution (C), with Nitrogen (-N), Phosphorus (-P), Potassium (-K), Calcium (-Ca), Magnesium (-Mg), and Sulfur (-S) omission 


\section{Conclusions}

1. The omission of macronutrients caused visual nutritional deficiency symptoms in young 'cedro doce' plants.

2. In general, $\mathrm{P}$ and $\mathrm{N}$ omission caused the least development of plants. This result indicates that 'cedro doce' is a very demanding species in both nutrients, especially $\mathrm{P}$.

\section{Literature Cited}

Andrade, M. L. F. de; Boaretto A. E. Deficiência nutricional em plantas jovens de aroeira-pimenteira (Schinus terebinthifolius Raddi). Scientia Forestalis, v.40, p.383-392, 2012.

Aquino, S. T. M. de; Batista, K. D.; Santos, R. F. dos; Souza, G. S. Sintomas visuais de deficiência nutricional de cedro doce. In: Congresso Nacional de Meio Ambiente de Poços de Caldas, 13, 2016, Poços de Caldas. Anais... Poços de Caldas: GSC, 2016.

Arco-Verde, M. F.; Moreira, M. A. B. Potencialidades e usos do cedro doce (Bombacopsis quinata) no estado de Roraima. Boa Vista: Embrapa Roraima, 2002. 14p. Documentos, 10

Camacho, M. A.; Camara, A. P.; Zardin, A. R. Diagnose visual de deficiência de nutrientes em mudas de Bombacopsis glabra. Cerne, v.20, p.427-431, 2014. https://doi.org/10.1590/0104776 0201420031304

Capaldi, F. R.; Gratão, P. L.; Reis, A. R.; Lima, L. W.; Azevedo, R. A. Sulfur metabolism and stress defense responses in plants. Tropical Plant Biology, v.8, p.60-73, 2015. https://doi.org/10.1007/s12042015-9152-1

Chen, L.; Zeng, J.; Xu, D. P.; Zhao, Z. G.; Guo, J. J. Macronutrient deficiency symptoms in Betula alnoides seedlings. Journal of Tropical Forest Science, v.22, p.403-413, 2009.

Corcioli, G.; Borges, J. D.; Jesus, R. P. de. Sintomas de deficiência nutricional de macronutrientes em mudas de Khaya ivorensis cultivadas em solução nutritiva. Pesquisa Florestal Brasileira, v.34, p.159-164, 2014. https://doi.org/10.4336/2014. pfb.34.78.641

Diaz, C.; Saliba-Colombani, V.; Loudet, O.; Belluomo, P.; Moreau, L.; Daniel-Vedele, F.; Morot-Gaudry, J. F.; Masclaux-Daubresse, C. Leaf yellowing and anthocyanin accumulation are two genetically independent strategies in response to nitrogen limitation in Arabidopsis thaliana. Plant and Cell Physiology, v.47, p.74-83, 2006. https://doi.org/10.1093/pcp/pci225

Ferreira, D. F. Sisvar: Um programa para análise e ensino de estatística. Revista Científica Symposium, v.6, p.36-41, 2008.

Fonseca, M. B.; França, M. G. C.; Zonta, E.; Giorni, V. Crescimento inicial de Dimorphandra wilsonii (Fabaceae - Caesalpinioideae) em diferentes condições de fertilidade em solo de cerrado. Acta Botânica Brasileira, v.24, p.322-327, 2010. https://doi.org/10.1590/ S0102-33062010000200003

Halfeld-Vieira, B.; Ferreira, L. M. M.; Nechet, K. L. Bombacopsis quinata: A new host for Oidiopsis haplophylli in Brazil. Plant Pathology, v.56, p.1040-1040, 2007. https://doi.org/10.1111/ j.1365-3059.2007.01639.x

Kitajima, K.; Hogan, K. P. Increases of chlorophyll a/b ratios during acclimation of tropical woody seedlings to nitrogen limitation and high light. Plant, Cell and Environment, v.26, p.857-865, 2003. https://doi.org/10.1046/j.1365-3040.2003.01017.x
Locatelli, M.; Macêdo, R. de S.; Vieira, A. H. Avaliação de altura e diâmetro das mudas de cedro rosa (Cedrela odorata L.) submetidas a diferentes deficiências nutricionais. Revista Brasileira de Biociências, v.5, p.645-647, 2007.

Maillard, A.; Diquélou, S.; Billard, V.; Laîné, P.; Garnica, M.; Prudent, M.; Garcia-Mina, J. M.; Yvin, J. C.; Ourry, A. Leaf mineral nutrient remobilization during leaf senescence and modulation by nutrient deficiency. Frontiers in Plant Science, v.6, p.1-15, 2015. https://doi.org/10.3389/fpls.2015.00317

Malavolta, E.; Vitti, G. C.; Oliveira, S. A. Avaliação do estado nutricional das plantas: Princípios e aplicações. 2.ed. Piracicaba: Editora Potafos, 1997. 319p.

Marschner, H. Mineral nutrition of higher plants. London: Academic Press, 1995. 889p.

Moretti, B. da S.; Furtini Neto, A. E.; Pinto, S. I. do C.; Furtini, I. V.; Magalhães, C. A. de S. Crescimento e nutrição mineral de mudas de cedro australiano (Toona ciliata) sob omissão de nutrientes. Cerne, v.17, p.453-463, 2011. https://doi.org/10.1590/S010477602011000400003

Muñoz-Huerta, R. F.; Guevara-Gonzalez, R. G.; Contreras-Medina, L. M.; Torres-Pacheco, I.; Prado-Olivarez, J.; Ocampo-Velazquez, R. V. A review of methods for sensing the nitrogen status in plants: Advantages, disadvantages and recent advances. Sensors, v.13, p.10823-10843, 2013. https://doi.org/10.3390/s130810823

Nemie-Feyissa, D.; Olafsdottir, S. M.; Heidari, B.; Lillo, C. Nitrogen depletion and small R3-MYB transcription factors affecting anthocyanin accumulation in Arabidopsis leaves. Phytochemistry, v.98, p.34-40, 2014. https://doi.org/10.1016/j. phytochem.2013.12.006

Rocha, S. A.; Garcia, G. O.; Lougon, M. S.; Cecílio, R. A.; Caldeira, M. V. W. Crescimento e nutrição foliar de mudas de Eucalyptus sp. irrigadas com diferentes qualidades de água. Revista de Ciências Agrárias, v.37, p.141-151, 2014.

Shen, J.; Yuan, L.; Zhang, J.; Li, H.; Bai, Z.; Chen, X.; Zhang, W.; Zhang, F. Phosphorus dynamics: From soil to plant. Plant Physiology, v.156, p.997-1005, 2011. https://doi.org/10.1104/ pp.111.175232

Sorreano, M. C. M.; Malavolta, E.; Silva, D. H. da; Cabral, C. P.; Rodrigues, R. R. Deficiência de macronutrientes em mudas de sangra d'água (Croton urucurana, Baill.). Cerne, v.17, p.347-352, 2011. https://doi.org/10.1590/S0104-77602011000300008

Sorreano, M. C. M.; Rodrigues, R. R.; Boareto, A. E. Guia de nutrição para espécies florestais nativas. 1.ed. São Paulo: Oficina de Textos, 2012. 254p.

Souza, C. A. S. de; Tucci, C. A. F.; Silva, J. F. da; Ribeiro, W. O. Exigências nutricionais e crescimento de plantas de mogno (Swietenia macrophylla King.). Acta Amazônica, v.40, p.515522, 2010. https://doi.org/10.1590/S0044-59672010000300010

Souza, P. A. de; Venturin, N.; Macedo, L. R. G. de. Adubação mineral do ipê-roxo. Ciência Florestal, v.16, p.261-270, 2006. https://doi. org/10.5902/198050981907

Valeri, S. V.; Pizzaia, L. G. E.; Sá, A. F. L. de; Cruz, M. C. P. da. Efeitos da omissão de nutrientes em plantas de Caesalpinia echinata. Cerne, v.20, p.73-80, 2014. https://doi.org/10.1590/S010477602014000100010 
Vieira, C.R.; Weber, O.L.dosS.;Scaramuzza,J.F.Omissão demacronutrientes no crescimento inicial de Tabebuia ochraceae. Ambiência, v.12, p.869883, 2016. https://doi.org/10.5935/ambiencia.2016.04.08

Vieira, C. R.; Weber, O. L. dos S.; Scaramuzza, J. F.; Costa, A. C.; Souza T. R. de. Descrição de sintomas visuais em função das deficiências de macronutrientes em mudas de cerejeira (Amburana acreana). Revista Floresta, v.41, p.789-796, 2011.https://doi.org/10.5380/rf.v41i4.25343
Vieira, H.; Chaves, L. H. G.; Viégas, R. A. Crescimento inicial de moringa (Moringa oleifera Lam) sob omissão de nutrientes. Revista Caatinga, v.21, p.51-56, 2008.

Wallau, R. L. R. de; Soares, A. de P.; Camargos, S. L. Concentração e acúmulo de macronutrientes em mudas de mogno cultivadas em solução nutritiva. Revista de Ciências Agro-Ambientais, v.6, p.1-12, 2008. 